\title{
A Study on Improving the Financing Environment of Small and Micro Enterprises - Based on Taizhou Model
}

\author{
Jieping Cai, Aijia Wang* \\ School of Economics and Trade, Guangzhou Xinhua University, Dongguan 523133, Guangdong Province, China \\ *Corresponding author: Aijia Wang, wangaijia@xhsysu.edu.cn
}

Copyright: ( $) 2022$ Author(s). This is an open-access article distributed under the terms of the Creative Commons Attribution License (CC BY 4.0), permitting distribution and reproduction in any medium, provided the original work is cited.

\begin{abstract}
China's small and micro enterprises have always had the typical characteristics of "five, six, seven, eight, nine," which are important supports to expand employment and improve people's livelihood. However, the current proportion of these enterprises in obtaining bank loans does not commensurate with the proportion of small, medium, and micro enterprises in the total economic aggregate. The financing dilemma of small and micro enterprises still exists. In consideration of the financing status of small and micro enterprises, this study analyzes the constraints of small and micro enterprises in financing, such as the difficulty in mortgage, difficulty in obtaining loans, and difficulty in guaranteeing. This study sorts out Taizhou's practical experience and links its operation mechanism of "two platforms, one fund, and one index." Finally, by learning from its successful experience, how to utilize the environment and the trend of big data will be further discussed, so as to form a scalable and sustainable financing method and path. This will provide a reference for improving the financing environment of small and micro enterprises.
\end{abstract}

Keywords: Small and micro enterprises; Financing; Taizhou; "Two platforms, one fund, and one index"; Financing environment

Online publication: February 23, 2022

\section{Introduction}

China's small and micro enterprises have always had the typical characteristics of "five, six, seven, eight, nine," which are important supports for expanding employment and improving people's livelihood. As of July 2021, the number of small, medium, and micro enterprises in China reached 143 million, accounting for $94 \%$ of the total number of enterprises in China. Small and micro enterprises contribute about $50 \%$ of tax revenue and $60 \%$ of GDP, as well as create $70 \%$ of scientific research achievements and $80 \%$ of urban employment, becoming the main players of the country's national economy ${ }^{[4]}$. At the end of the third quarter of 2021, the balance of loans of financial institutions was 189.46 trillion yuan. The balance of inclusive loans to small and micro enterprises totaled 18.59 trillion yuan, showing that the current proportion of small, medium, and micro enterprises in obtaining bank loans does not commensurate with the proportion of small, medium, and micro enterprises in total economic aggregate. The financing dilemma of small and micro enterprises still exists. 


\section{Constraints on the financing difficulties of small and micro enterprises}

Restricted by assets scale and other factors, credit financing by financial institutions is still the main way of external financing for small and micro enterprises. At present, the establishment of the financial system in China is flawed; in addition, its venture capital and gem entry threshold are high. Small, medium, and micro enterprises face difficulty in obtaining direct financing. As vulnerable parties, the vast majority of financial institutions require small and micro enterprises to provide guarantees in view of their small-scale operation and short life span, which undoubtedly brings financing difficulties to them. In terms of the existing financing environment and financing supply, the financing constraints of small and micro enterprises include mortgage difficulty, guarantee difficulty, and loan difficulty.

\subsection{The lack of mortgage conditions leads to mortgage difficulties}

According to Article 179 of the Property Law of the People's Republic of China and Article 3 of the Management Measures for Mortgage Loans, the necessary condition for an enterprise to obtain loans is to have a certain number of fixed assets as collateral. Bank lending targets must meet credit standards, dynamic growth, and other requirements to reduce loan risk and bad debt rate. The majority of small and micro enterprises lack actual collateral and do not have mortgage conditions. The backward credit guarantee mechanism increases the difficulty for small and micro enterprises to obtain credit guarantee. Even if these enterprises have several mortgageable properties, it is difficult for asset appraisal companies to unify the market evaluation standards of assets and mortgaged properties, which leads to mortgage difficulties.

\subsection{The reluctance of commercial banks to lend leads to difficulties in obtaining loans}

Traditional financial institutions consider multiple factors prior to lending. In addition to scale effect and liquidity of funds, they also consider the credit status and scale of operation. As small and micro enterprises are born with the inherent shortcoming of "low credit rating and short life span," commercial banks tend to lend to large and medium-sized enterprises with good credit records and complete capital supply chains. In addition, due to the limited authority of grass-roots branches of commercial banks and the long loan approval time, it is difficult for small and micro enterprises to obtain loans. It is an indisputable fact that small and micro enterprises have low access to credit.

\subsection{The difficulty in forming a joint guarantee relationship leads to difficulties in guaranteeing}

Due to the operating characteristics of small and micro enterprises, including the small proportion of fixed assets and the long payment recovery period, it is often difficult for small and micro enterprises to find suitable guarantors or credit guarantee institutions to guarantee them. Meanwhile, small and micro enterprises with good benefits are reluctant to form joint guarantee relationships with other companies, as the untrustworthy behavior of other companies in the repayment of loans will become the sword of Damocles to punish these enterprises. As long as there is a problem in one link in the chain of joint guarantee, the entire capital chain will be interrupted, and the mutual guarantor will be affected. Over time, it is difficult to form a joint guarantee relationship between these enterprises, thus making the joint guarantee mechanism unsustainable ${ }^{[5]}$.

\section{Taizhou's successful experience of "two platforms, one fund, and one index"}

Since the approval of the national financial service reform and innovation pilot zone, Taizhou City, Zhejiang Province has made effective breakthroughs in exploring the improvement of the financing environment and solving the problems of difficult financing, expensive financing, as well as slow financing. 
This can be used as a typical representative and successful experience in cracking down on the bailout of small and micro enterprises across the country. Among them, the "two platforms, one fund, and one index" model is particularly eye-catching.

The "two platforms, one fund, and one index" model reflects China's leading credit information sharing platform, the nationwide promotion of the trademark exclusive right pledge financing platform, China's first small and micro enterprise credit guarantee fund ${ }^{[2]}$, and China's first small and micro financial index. This model is a joint construction by the local government and major local banks, with full coverage of funds and government policy support. Based on the construction of "two platforms, one fund, and one index," Taizhou responds to the change and transformation of the financial digitization trend and competition pattern, improves the financing environment of small and micro enterprises, summarizes the experience that can be promoted to the whole country, and forms a replicable as well as portable "Taizhou model."

\subsection{Taizhou's "two platforms, one fund, one index" model}

\subsubsection{Partner organizations}

In the "two platforms, one fund, one index" model, the government helps to build the credit guarantee fund and construct the credit information sharing platform as well as the trademark exclusive right pledge financing platform through the accumulation of various organs and social information. As guides, Taizhou Bank and other commercial banks escort the financing of small and micro enterprises. Adhering to the linkage between provinces, cities, and counties, as well as the coordination between government, enterprises, and banks, a set of operation modes of financing services is explored, and a "financial format" is formed to promote the reshaping of the overall financing environment of "financial ecology" [6].

\subsubsection{Business ability}

The "two platforms, one fund, and one index" model has two major businesses (initial loan and renewed loan), realizing full financing coverage for small and micro enterprises, and even involving financing businesses from different regions of the same province and also other provinces. Both the initial loan and the renewed loan basically achieve zero cycle. The whole loan renewal process has been shortened from three days to 15 minutes. Since the establishment of Taizhou's "two platforms, one fund, one index" model, it has saved about 2.185 billion yuan in relending costs for small and micro enterprises every year, benefiting nearly 20,000 enterprises.

\subsubsection{Operation mode}

Taizhou's "two platforms, one fund, and one index" model is based on guarantee fund and supported by two information sharing platforms (leading credit information sharing platform and trademark exclusive right pledge financing platform), which are promoted nationwide, to provide special services for small and micro enterprises. It is responsible for docking with cooperative institutions, undertaking loan projects, implementing businesses, providing multiple financing channels and various financing methods for small and micro enterprises, as well as playing an important role as a bridge.

The basic mode of operation is shown in Figure 1. 


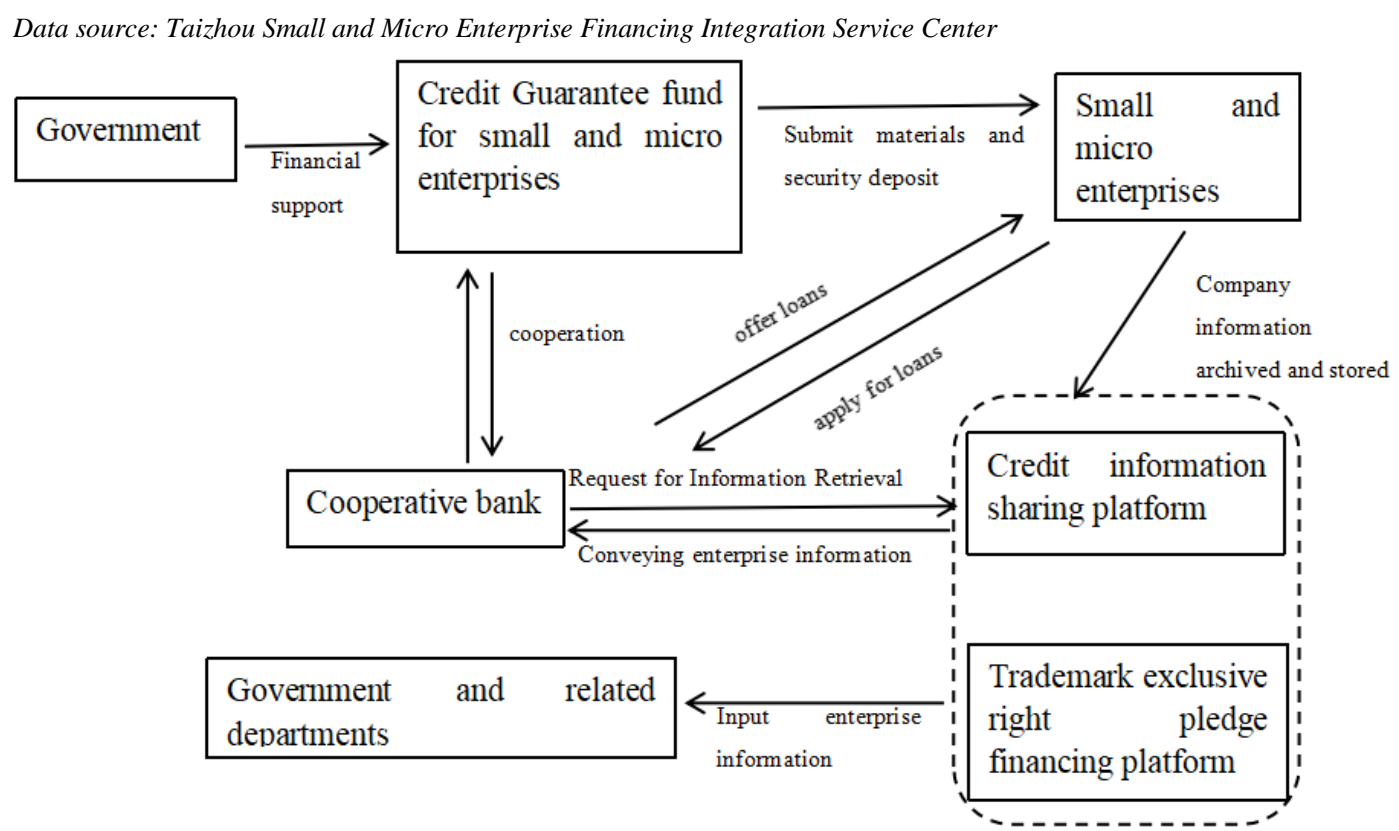

Figure 1. The operation mode of Taizhou's "two platforms, one fund, and one index" model

\subsection{Taizhou's successful experience with the "two platforms, one fund, and one index" model}

The "two platforms, one fund, and one index" model, as a typical successful example of financing platform for small and micro enterprises, is summarized below.

First of all, it seizes the opportunity of the era of big data and uses it to build a systematic credit information database as well as an enterprise virtual collateral gene database. The "two platforms, one fund, and one index" model mainly serves high-quality small and micro enterprises. Qualified small and micro enterprises can apply for loans by providing credit, trademarks, intellectual property rights, pollution rights, and other guarantees to relevant loan platforms, thus averting the problem of the lack of collateral and guarantee. The government has jointly established a unified credit information sharing platform for small and micro enterprises with the People's Bank of China as well as other social information platforms. They invested in the construction of credit guarantee funds, encouraged major investment institutions, banks, and all sectors of the society to participate in the construction of guarantee funds, widely absorbed investment funds, as well as established the framework of credit guarantee funds. The lending platform will call the information sharing platform to confirm the credit rating of those enterprises that have sent in their application for loans. This fundamentally solves the current situation of low credit and the unwillingness of banks to lend due to information asymmetry ${ }^{[1]}$.

Secondly, it optimizes the process and builds a platform for small and micro enterprises as a "bridge." The "two platforms, one fund, and one index" model eliminates several constraints, such as complicated process and slow approval, as well as realizes a virtuous cycle of zero-cycle financing and the fast application of small and micro enterprises and bank lending, with the characteristics of "zero cycle, zero cost, and zero threshold" [6]. With the help of big data information on the platform, banks can quickly conduct a series of loan works, such as pre-loan investigation, approval during the loan, and post-loan management for small and micro enterprises in terms of finance, as well as provide special extension services for those with operating difficulties. Small and micro enterprises tend to use their own only credit, goodwill, trademarks, and other virtual collaterals to guarantee loans effectively. Through efficient, highquality, and preferential loan services, diversified financial products are offered to serve small and micro enterprises, a variety of virtual collateral application channels are opened, and an information exchange 
bridge is built for small and micro enterprises as well as the participating banks, with the advantages of wide coverage, convenience, and benefit to the people.

Finally, it establishes and improves the trust-breaking punishment mechanism and risk prevention mechanism of small and micro enterprises to promote the maintenance of good credit investigation. With the "two platforms, one fund, and one index" model, Taizhou has accumulated more than 4,000 items of credit information in 118 categories from more than 30 departments ${ }^{[6]}$, including warnings on the blacklist of trust-breaking and the punishment of trust-breaking. When small and micro enterprises have borrowing needs, financial institutions can $\log$ on to the platform to query and obtain credit information, thus alleviating information asymmetry between banks and enterprises to a certain extent. The innovative development of the model drives the development of small and micro enterprises in Taizhou and benefits the whole province as well as the whole country.

\section{Promotable paths to improve the financing environment of small and micro enterprises}

It is a long-term project to establish and improve the financing environment of small and micro enterprises. They need to improve their own competitiveness as well as the cooperation of relevant departments and credit guarantee institutions. How to make good use of financing methods under the big data trend to solve the issue of financing requiring in-depth research?

First, a financing and credit service platform should be established. All sectors of the society should jointly build a financing credit service platform on the basis of data standardization and standard unification. The government-led "Xinyidai" platform is a good example. All sectors of the society should not only speed up the construction of the platform's functions and promote the development of the platform's personalized functions, but also increase the construction of the financial refined service function system in various cities and industries. Relying on the national credit information sharing platform ("Xinyidai"), a comprehensive public credit evaluation system should be designed in line with the operating characteristics of small and micro enterprises ${ }^{[1]}$. In regard to the credit rating of small and micro enterprises, enterprise managers should pay attention to the quality of the enterprise, especially the overall situation rating of the enterprise in terms of its quality, including the quality rating of the enterprise leadership group, the rating of the business management ability of the enterprise, and the rating of the enterprise competitiveness.

Secondly, policy support is necessary. The government takes the lead in formulating relevant standards and norms, regulating the operation of guarantee institutions, and giving full play to the role of local governments and policies. Local government departments should further speed up the implementation of policies and increase the intensity of supporting policies. Relevant departments should issue special support policies, make good use of existing inclusive financial support policies, various funds, and other resources, fully mobilize the enthusiasm of local governments, encourage qualified local governments to set up special funds, share out the financing risks of small and micro enterprises, as well as reduce the financing costs ${ }^{[7]}$. At the same time, under the guidance of the government, all relevant departments should accelerate the improvement of the credit information collection and sharing mechanism by promoting the establishment and improvement of the credit information sharing mechanism, making good use of information resources, such as the national credit information sharing platform and the international trade "single window" platform. They should also explore ways to solve the issue of information asymmetry between banks and enterprises.

Thirdly, public credit institutions should gradually establish a default risk prevention and disposal mechanism. The risk sharing mechanism and risk compensation mechanism are important guarantees for the healthy development of public credit institutions. Financial institutions should be encouraged to establish a multilevel risk warning and management system based on FinTech as well as realize a risk prevention and disposal mechanism with three interconnected parts: pre-loan, in-loan, and post-loan. They 
should also establish an online compulsory notary mechanism to speed up the resolution of debt disputes. Relying on the national credit information sharing platform, the repayment ability and willingness of enterprises can be evaluated according to the credit data accumulated by enterprises in their past operations, so as to effectively control loan risks. In addition, joint punishment should be executed on debtors who break faith to serious acts of malicious evasion or rejection of debts.

\section{Conclusion}

In short, a joint risk control mechanism should be established between relevant institutions. Joint risk control refers to risk sharing. Financial institutions, guarantee institutions, insurance institutions, credit service institutions, the government, and other parties should carry out reasonable system design to build a multiparty risk sharing mechanism. Financial institutions should actively respond to the settlement, achieve win-win results for both sides, help the development of small and micro enterprises, as well as effectively realize risk prevention and control. The government should give play to the role of associations of various industries and social organizations, strengthen the publicity and training of small and micro enterprises on credit policies, and help the enterprises improve their internal credit management system. Guarantee institutions should improve the product system of the platform, provide diversified solutions for financing, and achieve precise negative reduction. At the same time, in the field of industrial application, insurance also plays a role for small and micro enterprises in bidding, medical care, transportation, and other fields to achieve burden reduction. Credit service institutions should establish an assessment mechanism conducive to promoting "credit and easy lending," mobilize the enthusiasm of various financial institutions and credit service institutions, as well as fulfill the obligation of inclusive finance. Under the premise of controllable risks, the national credit and easy loan platform should be promoted and play effective roles in various places.

\section{Funding}

This research is funded by the Public Management Construction Project of Characteristic Key Discipline from Guangdong Province, China in 2016 (Project Number: 2020STSZD01); the Project of Finance Course Teaching and Research Section of Guangzhou Xinhua University (Project Number: 2021JYS001); the Higher Education Teaching Reform Project of Guangzhou Xinhua University, "Research on Teaching Reform of Inquiry Teaching in the Course of 'Principles of Economics"” (Project Number: 2020J028).

\section{Disclosure statement}

The authors declare that there is no conflict of interest.

\section{References}

[1] Guo W, Zhou H, 2021, Public Credit Information Value-Added and Practice Path Based on Information Two-factor Theory. Macroeconomic Management, 2021(6): 7. DOI: 10.19709/j.cnki.113199/f.2021.06.010

[2] Han J, 2018, How Do Small and Micro Enterprises Get Out of Financing Dilemma?. Rural Finance Research, 2018(09): 40-43. DOI: 10.16127/j.cnki.issn1003-1812.2018.09.008

[3] Li S, 2020, Analysis of Credit Guarantee Risk Prevention Measures of Financing Guarantee Companies. Time Finance, 2020(18): 2. 
[4] Liao L, Li P, Yuan W, et al., 2020, Recovery of Micro, Medium and Small Economies in the Context of the Epidemic: Based on the Operation Data of Millions of Micro, Medium and Small Enterprises. Tsinghua Financial Review, 2020(5): 8. DOI: 10.19409/j.cnki.thf-review.2020.05.029

[5] Song G, Wang C, Dong Y, 2016, Research on Mutual Assistance and Joint Guarantee Model of HighTech SMEs Based on Social Capital Theory: A Case Study of Guangdong Province. Financial Development Research, 2016(4): 7. DOI: 10.19647/j.cnki.37-1462/f.2016.04.006

[6] Wang W, 2015, The Market-Oriented Privatization of Small and Micro Finance: Inspiration and Reference from Taizhou Model. Theoretical Horizon, 2015(10): 3. DOI: 10.19632/j.cnki.113953/a.2015.10.012

[7] Wei G, 2010, Increasing Financing Supply to Alleviate Financing Difficulties of Small and Micro Enterprises. China Finance, 2010(3): 3.

[8] Lu H, Rong K, 2018, Unbounded Returns and the Possibility of Credit Rationing: A Note on the Stiglitz-Weiss and Arnold-Riley Models. Journal of Mathematical Economics, 75: 67-70. DOI: 10.1016/j.jmateco.2017.12.009

[9] Colombo MG, Grilli L, 2007, Funding Gaps? Access to Bank Loans by High-Tech Start-Ups. Small Business Economics, 29(1-2): 25-46. 